\title{
Physical Examination Modified Reported Term
}

National Cancer Institute

\section{Source}

National Cancer Institute. Physical Examination Modified Reported Term. NCI Thesaurus.

Code C83351.

An indication or description of a change in a physical examination. 